\title{
PEMANFAATAN MODAL SOSIAL DERI ASTADAN ZOHIRIN SAYUTI PADA PILKADA SAWAHLUNTO TAHUN 2018
}

\author{
Wahyuni Chairunisa ${ }^{1}$, Indah Adi Putri ${ }^{2}$, Dewi Anggraini ${ }^{3}$ \\ 1'Jurusan Ilmu Politik, Fisip, Universitas Andalas, Wahyinichairunisa66@gmail.com \\ ${ }^{2}$ Jurusan Ilmu Politik, Fisip, Universitas Andalas \\ ${ }^{3}$ Jurusan Ilmu Politik, Fisip, Universitas Andalas
}

\begin{abstract}
Abstrak
Pada pemilihan Walikota Sawahlunto tahun 2018 pasangan Deri Asta dan Zohirin Sayuti unggul dalam perhitungan 16.367 suara atau 47,28 persen suara sah. Kekalahan Ali Yusuf di pemilihan Umum Walikota di Sawahlunto merupakan hal yang mengejutkan karena kandidat yang kemungkinan akan memenangkan pemilukada jikalau ia memiliki modal yang terbangun. Tetapi melihat modal yang dimiliki Deri Asta dan Zohirin Sayuti masih kurang dibandingkan dengan calon Petahana Ali Yusuf, maka rumusan penelitian pada penelitian ini adalah bagaimana pemanfaatan modal sosial, ekonomi, dan politik dalam kemenangan Deri Asta dan Zohirin Sayuti pada pemilihan Walikota Sawahlunto tahun 2018? Penelitian ini menggunakan teori Modal Sosial, Modal Politik, Modal ekonomi milik Bourdieu dan Strategi politik milik Peter Schorder. Penelitian ini menggunakan metode kualitatif dengan pendekatan deskriptif. Berdasarkan hasil temuan Deri Asta dan Zohirin Sayuti melakukan pemanfaatan modal baik modal sosial, politik dan ekonomi. Diantaranya pengarahan suara karyawan tambang melalui jaringan pengusaha tambang yang ia miliki, Motor Trail Adventure, ikatan keluarga Pariaman dan Tanah Datar, Dukungan dan kampanye terselubung dari berbagai kelompok. Disamping itu partai membentuk tim sukses dan relawan yang berjumlah 600 orang. Dari sisi ekomoni berupa bantuan dana yang diberikan oleh jaringan pengusaha tambang, memberikan gaji kepada relawan.
\end{abstract}

Kata Kunci: Pemilukada; Modal Sosial; Modal Politik; Modal Ekonomi; Strategi Politik

\begin{abstract}
In the election of the Mayor of Sawahlunto in 2018 the couple Deri Asta and Zohirin Sayuti excelled in counting 16,367 votes or 47.28 percent of valid votes. The defeat of Ali Yusuf in the general election of the Mayor in Sawahlunto is surprising because the candidate is likely to win the election if he has built capital. But seeing that the capital owned by Deri Asta and Zohirin Sayuti is still insufficient compared to candidate Petahana Ali Yusuf, the research formulation in this study is how to utilize social, economic and political capital in the victory of Deri Asta and Zohirin Sayuti in the election of Mayor of Sawahlunto in 2018? This research uses the theory of Social Capital, Political Capital, Bourdieu's economic capital and Peter Schorder's political strategy. This research uses a qualitative method with a descriptive approach. Based on the findings of Deri Asta and Zohirin Sayuti made use of capital both social, political and economic capital. Among them were directing the voices of mine employees through the network of mining entrepreneurs he owned, Motor Trail Adventure, the Pariaman and Tanah Datar family ties, support and covert campaigns from various groups. Besides this the party formed a success team and volunteers totaling 600 people. From the economic side in the form of financial assistance provided by the mining entrepreneur network, providing salaries to volunteers.
\end{abstract}

Keywords: Regional Head Election; Social Capital; Political Capital; Economic Capital; Political Strategy 


\section{PENDAhuluan}

Sistem negara demokrasi memiliki ruang lingkup yang sangat luas. Perkembangan demokrasi pada suatu negara dapat diukur. Dalam mengukur perkembangan demokrasi tersebut ada beberapa ciri-ciri yang dapat mencerminkan sebuah negara atau daerah itu telah menjalankan demokrasi, salah satunya dengan mengukur tingkat partisipasi politik masyarakat. Partisispasi politik masyarakat dapat dijadikan salah satu tolak ukur sejauh mana demokrasi itu berjalan, salahsatunya partisipasi pada pemilihan umum. Hasil pemilihan umum yang diselenggarakan dalam suasana keterbukaan dengan kebebasan berpendapat dan kebebasan berserikat, dianggap mencerminkan dengan agak akurat partisipasi serta aspirasi masyarakat ${ }^{1}$.

Pada tanggal 27 Juni 2018 telah dilaksanakan pemilihan umum kepala daerah serentak (Pilkada Serentak). Kota Sawahlunto adalah salah satu daerah dari empat daerah yang berada di Propinsi Sumatera Barat yang ikut dalam pilkada serentak tersebut untuk memilih Walikota dan Wakil Walikota periode 2018-2023.

Dalam pemilihan kepala daerah tersebut, terdapat tiga pasangan calon yang berkompentisi untuk menjadi Walikota dan Wakil Walikota Sawahlunto. Pasangan calon Walikota dan Wakil Walikota tersebut adalah Pasangan dengan nomor urut satu, pasangan Fauzy Hasan dan Zohirin Sayuti. Pasangan nomor urut dua adalah Ali Yusuf dan Ismed. Dan pasangan terakhir dengan nomor urut tiga adalah Deri Asta dan Zohirin Sayuti. Untuk pasangan calon Walikota Fauzy Hasan dan Dasrial Ery diusung partai Demokrat dan PDIP, kemudian pasangan Ali Yusuf dan Ismed diusung partai Golkar, PKS, dan PKPI. Terakhir, pasangan Deri Asta dan Zohirin Sayuti diusung oleh partai PAN, PPP, NASDEM ${ }^{2}$.

\footnotetext{
${ }^{1}$ Miriam Budiardjo,2008, Dasar-Dasar Ilmu Politik. Gramedia Pustaka Utama, Jakarta, hlm 461

${ }^{2}$ PilkadaSawahlunto2018. https://sumbar.antaranews.com/.Diakses pada tanggal 8 September 2018 Pukul 12.01 WIB
} 
Tabel 1.1

Partai Pengusung Calon Walikota dan Wakil Walikota Sawahlunto

\begin{tabular}{cccc}
\hline No & Nama Pasangan & $\begin{array}{c}\text { Parpol } \\
\text { Pengusung }\end{array}$ & $\begin{array}{c}\text { Jumlah } \\
\text { Dukungan/ Suara }\end{array}$ \\
\hline & & Demokrat, & 5 Kursi \\
1 & $\begin{array}{c}\text { Fauzy Hasan } \\
\text { dan Dasrial Ery }\end{array}$ & PDIP & \\
& Ali Yusuf dan & Golkar, PKS, & 8 Kursi \\
2 & Ismed & PKPI & \\
& $\begin{array}{c}\text { Deri Asta dan } \\
\text { Zohirin Sayuti }\end{array}$ & $\begin{array}{c}\text { PAN, PPP, } \\
\text { NASDEM }\end{array}$ & 7 Kursi
\end{tabular}

Sumber Data : Website KPUD Sawahlunto 2018

Dari proses pilkada Kota Sawahlunto tersebut, didapatkan hasil perolehan suara terbanyak yaitu pasangan Deri Asta dan Zohirin Sayuti dengan jumlah suara 16.319 suara atau $47,08 \%$ dari jumlah suara sah pada pilkada tersebut. Sedangkan pasangan yang menempati posisi nomor dua perolehan suara terbanyak adalah pasangan Ali Yusuf dan Ismed dengan perolehan sebanyak 11. 681 suara atau 33,70 \% suara sah. Posisi terakhir dengan perolehan suara 6.659 suara atau 19,21\% suara sah adalah pasangan Fauzy Hasan dan Dasrial Ery.

Tabel 1.2

Hasil Perolehan Suara Pilkada Kota Sawahlunto 2018

\begin{tabular}{cccc}
\hline No & Nama Pasangan & $\begin{array}{c}\text { Perolehan } \\
\text { Suara }\end{array}$ & Persentase \\
\hline 1 & $\begin{array}{c}\text { Fauzy Hasan dan } \\
\text { Dasrial Ery }\end{array}$ & 6.659 & $19,21 \%$ \\
2 & $\begin{array}{c}\text { Ali Yusuf dan } \\
\text { Ismed }\end{array}$ & 11.681 & $33,70 \%$ \\
3 & $\begin{array}{c}\text { Deri Asta dan } \\
\text { Zohirin Sayuti }\end{array}$ & 16.319 & $47,08 \%$ \\
\hline
\end{tabular}

Kemenangan pasangan Deri Asta dan Zohirin Sayuti dalam pilkada serentak Kota Sawahlunto cukup mengejutkan. Hal ini dikarenakan pasangan Deri Asta dan Zohirin Sayuti merupakan para calon dengan wajah baru di perpolitikan Kota Sawahlunto, dan para pesaing mereka merupakanpetahanadan politisi senior yang sudah banyak berkiprah di 
Kota Sawahlunto ${ }^{3}$. Sedangkan jika melihat latar belakang Deri Asta ialah seorang pengusaha di Kota Sawahlunto dan Zohirin Sayuti adalah birokrat yang cukup berpengalaman. Jika dibandingkan modal yang dimiliki oleh Deri Asta dan Zohirin Sayuti masih kurang dibandingkan dengan modal yang dimiliki oleh Ali Yusuf dan Ismed. Tetapi, pasangan Deri Asta dan Zohirin Sayuti yang memenangkan Kontestasi tersebut.

Maka dari itu peneliti berpandangan bahwasanya adanya modal yang dimiliki oleh kandidat yang ingin memenangkan pemilu harus dimanfaatkan secara optimal. Jika dilihat pasangan Deri Asta dan Zohirin Sayuti tidak memiliki banyak modal jika dibandingkan dengan pasangan petahana Ali Yusuf dan Ismed. Oleh Karena itu dalam hal ini, penulis berasumsi bahwa Deri Asta dan Zohirin Sayuti dapat memanfaatkan modal sosial, politik dan ekonomi dengan baik pada pemilihan Walikota Sawahlunto Tahun 2018 sehingga kemenangan berhasil didapatkan oleh pasangan tersebut karena telah mampu mengikat para pemilih dalam memberikan dukungan politik kepada tersebut.

Deri Asta adalah seorang pengusaha yang terbilang sukses menapaki usaha batu baranya di Talawi. Rekan-rekan sesama pengusaha batu bara sangat menyenangi sosok Deri Asta, hal itu terbukti hampir seluruh bos batu bara memberikan dukungan kepada dirinya. Bantuan tersebut bersifat moril maupun materil tanpa syarat apapun ${ }^{4}$. Hal ini menunjukan bahwa Deri Asta memiliki kedekatan dengan para pengusaha batu bara di Kota Sawahlunto. Pengusaha tersebut juga mempunyai peran yang penting terhadap kemenangan Deri Asta dan Zohirin Sayuti dalam pemilihan umum kepala daerah di Kota Sawahlunto. Dengan menjalin kedekatan dengan beberapa pengusaha tambang, memudahkan Deri Asta dan Zohirin untuk mendapatkan dukungan politik dari masyarakat, dan juga meningkatkan modal sosial dan modal ekonomi yang dipunyainya sehingga Deri Asta dan Zohirin dapat dimanfaatkan untuk memenangkan Pilkada Serentak Kota Sawahlunto tahun 2018.

Pasangan calon kepala daerah akan berpeluang besar memenangkan dan terpilih apabila memiliki akumulasi lebih dari satu modal ${ }^{5}$. asumsinya, semakin besar pasangan calon mampu mengakumulasikan ketiga modal itu, maka besar peluang untuk terpilih sebagai kepala daerah. Dalam modal sosial, modal ekonomi dan modal politik memiliki kualifikasi masing-masing yang mampu meningkatkan kredibilitas dari calon-calon dalam pemilihan umum. Maka rumusan penelitian pada penelitian ini adalah bagaimana

\footnotetext{
${ }^{3}$ Harian Haluan, 2018, Dua Petahan Tumbang Di Sumbar, www.harianshaluan.com.2018. Diakses pada 5 September 2018 pukul 10.07 Wib

${ }^{4}$ Kumparan.com. Terbongkar! Ternyata ini yang mendongkrak popularitas DERASZwww.Kumparan.com. diakses pada tanggal 7 Februari 2019 pukul 21.21

${ }_{5}^{5}$ Masyidan putri, 2015,Faktor kemenangan koalisi Suharsono-Halim dalam pemenangan pemilu kepala daerah Kabupaten Bantun Tahun 2015. Universitas Muhammadya Yogyakarta.
} 
pemanfaatan modal sosial, ekonomi, dan politik dalam kemenangan Deri Asta dan Zohirin Sayuti pada pemilihan Walikota Sawahlunto tahun 2018 ?

\section{Studi Literatur}

Dalam pemilihan umum seseorang dapat memenangkan pemilihan umum jika mempunyai modal yang kuat, strategi politik. Secara konseptual menurut Kacung Marijan tiga modal utama yang dimiliki oleh para calon yang akan mengikuti kontestasi dalam pemilukada yaitu (1) modal politik (political capital) (2) modal sosial (social capital) dan (3) modal ekonomi (economical capital). Ketiga modal ini dikatakan dapat mempengaruhi seorang kandidat dalam memperoleh dukungan dari masyarakat, di mana semakin besar akumulasi modal yang dimiliki olehseorang kandidat maka semakin besar pula dukungan yang diperoleh ${ }^{6}$. Dalam pemilihan umum bukan hanya modal yang dapat memenangkan pemilihan umum, tetapi bagaimana mengelola modal tersebut dengan strategi yang digunakan untuk memenangkan pemilihan tersebut. Hal ini yang menjadi salahsatu faktor kemenangan Deri Asta dan Zohirin Sayuti Pada pemilihan walikota Sawahlunto tahun 2018.

\section{Modal Politik}

Kandidat dalam pemilukada memerlukan dukungan politik diusung dari partai politik (koalisi partai). Partai politik adalah organisasi politik yang mengajukan kandidat dalam pemilukada dan wakada untuk mengisi jabatan politik di pemerintahan dan kemudian dipilih oleh rakyat sedangkan Pemilu adalah merupakan suatu cara atau sarana untuk menentukan orang-orang yang akan mewakili rakyat dalam menjalankan roda pemerintahan. Pilkada sebagai arena kompetisi antar kandidat calon kepala daerah yang dicalonkan oleh partai politik (koalisi partai), fungsi partai politik sebagai alat untuk memobilisasi dukungan relatif kecil sehingga kandidat yang ingin memenangkan pilkada harus sebanyak mungkin memanfaatkan jaringan organisasi-organisasi politik untuk memperoleh dukungan politik karena kompetisi lebih menonjol terhadap pengaruh figur kandidat $^{7}$. Casey mendefinisikan modal politik sebagai pendayagunaan keseluruhan jenis modal yang dimiliki seorang pelaku politik atau sebauh lembaga politik untuk menghasilkan tindakan politik. yang menguntungkan dan memperkuat posisi pelaku politik atau lembaga politik bersangkutan.

\footnotetext{
${ }^{6}$ Kacung Marijan, 2006, Demokratisasi di Daerah, Pelajaran dari Pilkada Secara Langsung. Pustka Eurka, Surabaya, hlm 89

${ }^{7}$ Siti Fatimah. 2018. Kampanye Sebagai Komunikasi Politik: Esensi dan Strategi dalam Pemilu. Jurnal. (1). Dipublikasikan. Universitas Diponegoro. Hlm 13
} 


\section{Modal Sosial}

Pierre Bourdieu 1970 (field, 2003) mendefinisikan modal sosial sebagai sumber daya aktual dan potensial yang dimiliki seseorang berasal dari jaringan sosial yang terlembagakan serta berlangsung terus menerus dalam bentuk pengakuan dan perkenalan timbal balik (atau dengan kata lain : keanggotaan dalam kelompok sosial) yang memberikan kepada anggotanya berbagai bentuk dukungan kolektif. Bourdieu juga menegaskan modal sosial sebagai sesuatu yang berhubungan satu dengan yang lain, baik ekonomi, budaya, maupun bentuk-bentuk social capital (modal sosial) berupa insitusi lokal atau kekayaan sumber daya alam. Pendapatnya menegaskan tentang modal sosial mengacu pada keuntungan dan kesempatan yang didapatkan seseorang di dalam masyarakat melalui keanggotaannya dalam entitas sosial tertentu (paguyuban, kelompok arisan, asosiasi tertentu).

Bourdieu mendefenisikan habitus sebagai pengkondisian yang dikaitkan dengan syarat-syarat keberadaan suatu kelas. Menurutnya sistem-sistem disposisi tahan waktu dan dapat diwariskan, sruktur-struktur yang membentuk adalah merupakan hasil dari suatu habitus.Dengan demikian habitus adalah hasil keterampilan yang menjadi tindakan praktis (tidak selalu disadari) yang kemudian diterjemahkan menjadi suatu kemampuan yang keliahatanya alamiah dan berkembang dalam lingkungan sosial tertentu.

Adapun ranah (field) lebih dipandang Bourdieu secara relasional daripada secara struktural. Ranah adalah jaringan relasi antarposisi objektif di dalamnya. Keberadaan relasirelasi ini terpisah dari kesadaran dan kehendak individu, ranah merupakan: 1) arena kekuatan sebagai upaya perjuangan untuk memperebutkan sumber daya atau modal dan juga untuk memperoleh akses tertentu yang dekat dengan hirarki kekuasaan dan, 2) semacam hubungan yang terstruktur dan tanpa di sadari mengatur posisi-posisi individu dan kelompok dalam tatanan masyarakat yang terbentuk secara spontan.

\section{Modal Ekonomi}

Modal ekonomi menurut Bourdieu merupakan sumber daya yang bisa menjadi sarana produksi dan sarana finansial. Modal ini paling mudah dikonversikan ke modalmodal lainnya ${ }^{8}$. Bourdieu juga berpendapat bahwa modal ekonomi ini dapat dengan cepat dikonversikan menjadi uang dan dapat dilembagakan dalam bentuk hak milik. Lebih jauh Bourdieu mengklasifikasi modal ekonomi dalam berbagai hal seperti: alat-alat dan produksi (mesin, tanah, buruh), materi (pendapatan benda-benda yang dimiliki) dan uang yang

\footnotetext{
${ }^{8}$ Opcit, Kacung Maridjan, Hlm 85
} 
dengan mudah digunakan untuk segala tujuan serta diwariskan dari satu generasi ke generasi berikut.

Modal Ekonomi yaitu dukungan ekonomi berupa dana politik baik itu berdasarkan sumbernya dari dana pribadi dan donatur, dan berdasarkan penggunaannya untuk bayar partai politik, kampanye dan beli suara, untuk pemenangan pilkada.

\section{Strategi Politik}

Peter Schroder, mendefinisikan strategi politik sebagai strategi atau cara yang digunakan untuk merealisasikan cita-cita politik. Walaupun dalam praktiknya penggunaan strategi politik sangat beragam, namun pada hakikatnya para politisi yang sedang merancang sebuah strategi tetap mengacu pada dua pola dasar, yakni pola ofensif (menyerang) dan defensif (bertahan) Pola strategi ofensif (menyerang) akan diperlukan bilamana seorang kandidat/partai politik ingin menarik pendukung baru maupun memperluas jumlah dukungan masyarakat. Biasanya kandidat maupun partai politik yang menggunakan pola strategi ofensif ini lebih dikenal sebagai pihak penantang maupun "pendatang baru" yang akan berkompetisi untuk mengincar kursi kekuasaan. Pola ofensif inilah yang disebut Schroder sebagai strategi memperluas pasar dan strategi menembus pasar, sebab pola strategi ini memiliki ciri-ciri sebagai berikut :

1. Selalu berusaha menampilkan perbedaan yang jelas dan menarik terhadap pihak pesaing yang ingin diambil alih pemilihnya.

2. Senantiasa menampilkan keuntungan-keuntungan yang akan didapatkan masyarakat bila mendukung pihaknya, yang tidak terdapat pada pihak pesaing.

3. Berusaha menawarkan keunggulan-keunggulan yang dimilikinya yang tidak ditemukan pada pihak pesaing

4. Selalu berupaya menjadi penyempurna dari program-program yang dimiliki pesaing.

5. Selalu menjanjikan perubahan

\section{METODE PENELITIAN}

Dalam penelitian ini menggunakan metode kualitatatif dengan tipe deskriptif untuk mengetahui bagaimana pemanfaatan modal sosial Deri Asta dan Zohirin Sayuti Pada Pemilihan Walikota Sawahlunto tahun 2018. Metode kualitatif ini dipandang oleh Creswell yaitu melakukan framingatau sudut pandang perilaku manusia dan keyakinan dalam sosial-politik-historis dan serta kualitatif deskriptif sendiri juga termasuk dalam paradigma Post Positivis (Creswell, 2007). Penggunaan pendekatan dan tipe penelitian ini bertujuan agar peneliti bisa menjelaskan dan menggambarkan secara tertulis tentang fenomena yang peneliti angkat untuk disusun kedalam laporan penelitian yang kompleks dan efisien. Sehingga apa yang menjadi tujuan dari penelitian ini dapat terjawab dengan 
baik. Berdasarkan penjelasan tersebut, peneliti anggap lebih dapat untuk menjelaskan permasalahan penelitian secara komprehensif sesuai dengan kondisi alamiah masalah.

\section{HASIL dan PEMBAHASAN}

a. Pemanfaatan Modal Sosial

Modal sosial lain yang dipunyai oleh Deri Asta adalah jaringan pengusaha tambang. Modal sosial tersebut tentu dimanfaatkan oleh calon ini menggunakan strategi yang tepat. Seorang pengusaha tambang tentu mempunyai karyawan yang banyak, hal tersebut dapat dimanfaatkan oleh pasangan ini untuk memperbanyak suara yang ia punyai. Hal tersebut sesuai dengan strategi yang dilakukan oleh Multiplikator menurut Schroder yaitu strategi memperluas pasar dengan melakukan kampanye pengantar.

Jhon Reflita, pengusaha batu bara menjelaskan bahwa ia mengarahkan karyawan tambangnya untuk memilih Deri Asta dan Zohirin Sayuti, selain itu ia juga mengarahkan karyawanya untuk mencari masa untuk mendukung Deri Asta dan Zohirin Sayuti, hal tersebut disampaikan dalam hasil wawancara berikut:

...kayak yang ambo sampaikan tadi ambo punyo masa yang kuat dek karyawan tambang wak rami yaitu sekitar 500 urang kalau dikalikan dua saja sudah seribu, beko disuruah cari masa agak sapuluah urang jadinyo lah 10.000 urang hal itu cukup diperhitungkan.

(Wawancara Dengan Bapak Jhon Reflita, (seperti yang telah saya sampaikan tadi bahwasanya saya punya masa yang kuat karena karyawan tambang saya banyak yaitu sekitar 500 orang kalau dikalikan dua saja sudah seribu, nanti disuruh cari masa sepuluh orang jadi sudah 10.000 orang hal itu cukup diperhitungkan)

Modal sosial yang pasangan ini punyai adalah dukungan dari kelompok sosial dan organisasi sosial antara lain kelompok tani, karangtaruna, dan pemuda. Kelompok tersebut tentu ada dimanfaatkan salahsatunya adalah kelompok tani. Nursyirwan menyatakan bahwa Deri Asta dan Zohirin Sayuti sering melakukan pertemuan dengan kelompok ini dan membahas beberapa hal yang siampaikan dalam hasil wawancara berikut:

...kalau jo kelompok tani tu acok dilakukan pertemuan, kadang disitu kami membahas apo yang akan dilakukan kalau pak Deri naiak, disitu kan bisa maambiak simpati kelompok tani tu.

(Wawancara Dengan Bapak Nursyirwan, Tim Pemenangan Paslon No. Urut 3, Di Kantor DPD Partai Nasdem Kota Sawahlunto, Pada Tanggal 28 Juli 2019)(pertemuan sering dilakukakan dengan kelempok tani, kadang dalam pertemuan tersebut kami membahas apa kebijakan yang akan diberlakukan untuk kelompok tani, hal tersebut bisa mengambil simpati kelompok tani tersebut) 
Melalui modal sosial yang ia miliki ia dapat manfaatkan melalui kegiatan-kegiatan, turun langsung ke masyarakat, bersosialisasi, strategi yang lama-kelamaan akan mendapatkan kepercayaan dari masyarakat agar memenangakan pemilihan Walikota Sawahlunto tahun 2018.

b. Pemanfaatan Modal Politik

Dalam pemilihan Walikota Sawahlunto modal politik yang dipunyai oleh Deri Asta dan Zohirin Sayuti antara lain adalah diusung dari tiga partai yang cukup mendominasi di Sawahlunto, mempunyai tim sukses yanng solid, menduduki jabatan politis dan didukung oleh tokoh politik di Kota Sawahlunto. dalam pemilihan tersebut modal politik merupakan salahsatu modal yang mengantarkan calon tersebut terhadap kemenangan. Partai politik membantu pasangan ini dalam kegiatan kampanye. Pasangan Deri Asta dan Zohirin Sayuti sering melakukan kegiatan blusukan ke semua tempat di Kota Sawahlunto. dalam kegiatan tersebut partai juga berpartisipasi yaitu ikut mendampingi kegiatan blusukan tersebut, setiap kali melaksanakan blusukan selalu ada perwakilan dari setiap partai untuk mendampingi pasangan tersebut. Hal tersebut disampaikan oleh Jhon Reflita dalam hasil wawancara berikut:

(Saat biasanya yang mewakili per partai ataupun tim sukses, biasanya dari empat partai itu ada yang mendampingi dalam kegiatan sosialisasi ataupun blusukan)

Deri Asta dan Zohirin Sayuti mempunyai tim sukses dan relawan yang jumlahnya banyak. Jumlah relawan yang dimiliki oleh tim ini adalah 600 orang, tim tersebut diarahkan untuk kampanye door to door, membagikan alat peraga kampanye ke masyarakat dan menentukan kegiatan dan wilayah kampanye, yang tujuanya untuk memperbanyak dukungan dari masyarakat. hal tersebut disampaikan oleh Alex Isrin sebagai sekretaris tim pemenangan Deri Asta dan Zohirin Sayuti sebagai berikut:

(relawan itu tugasnya seperti kampanye biasa lah, blusukan, pertemuan lalu disampaikan visi misi berupa leef fleet, memang rajin turun kabawah, beliau-beliau berdua itu ada ditempat-tempat tertentu, lalu yang menyusun jadwal kami berdua, misalnya didesa ini, didesa itu. Belum juga tim, belum pula emak-emak, dengan berbagai cara kadang dari rumah ke rumah, kadang disawah juga bisa berkampanye, tapi yang resmi pak Deri zohirin ini ada juga kami yang mengatur itu, dibuatkan izinnya pakai STTP)

c. Pemanfaatan Modal Ekonomi

Modal ekonomi juga berperan dalam kemenangan Deri Asta dan Zohirin Sayuti, dimana modal ekonomi tersebut dapat berfungsi sebagai penggerak mesin politik yang dipakai saat berkampanye. Dalam pemilihan Walikota Sawahlunto tahun 2018 Deri Asta dan Zohirin Sayuti mempunyai modal ekonomi yang cukup bersar. Hal tersebut diperoleh 
dari bantuan dari perusahaan tambang, pengusaha tambang dan Deri Asta juga merupakan orang yang mempunyai kekayaan yang cukup banyak. Modal ekonomi yang dipunyai oleh Deri Asta dan Zohirin Sayuti tentu dimanfaatkan dalam pilkada tersebut. Hal tersebut terlihat pada jumlah pengeluaran yang dikeluarkan oleh pasngan ini selama waktu kampanye yaitu kurang lebih Rp. 4.000.000.000,. dana tersebut digunakan untuk logistik selama kampanye, gaji relawan selama kampanye dan kebutuhan alat peraga kampanye lainya. Hal tersebut disampaikan oleh alex isrin dalam hasil wawancara berikut:

Pak Deri tahu tidak uangnya keluar empat miliar, contoh sosialisasi disuatu tempat anggap lah dananya seratus, kopinya snacknya kalau orang sini mintanya makan, ada pula daerah silungkang sate dimintanya, satu panci atau cawan sate itu satu setengah juta, nanti kalau dari satu panci itu dapatnya kalau porsi biasa itu seratus bungkus tapi kalau dikecilkan sedikit bisa dia mainkan seratus sepuluh itu bisa dagingnya tiga buah, kadang-kadang ada dua panci, kadang-kadang ada satu panci besoknya menyusul pula bon

Sesuai dengan hasil wawancara di atas pasangan Deri Asta dan Zohirin Sayuti memanfaatkan Modal Ekonomi yang dipunyainya dengan baik. Ia menggunakan modal tersebut untuk memperluas pasar dan mendapatkan simpati dari masyarakat. Modal ekonomi yang ia punyai juga dimanfaatkan untuk menggerakan mesin politik yang ia punyai yaitu tim relawan, semua hal tersebut dilakukan agar dapat memenangkan Pemilihan Walikota Sawahlunto tahun 2018

\section{KESIMPULAN}

Kontestasi pemilihan umum kepala daerah secara langsung memang sangat membuktikan sejauh mana aktor bersaing memperebutkan atau mempertahankan kekuasaan yang dimilikinya. Individu/aktor tentu mempersiapkan dirinya untuk mencalonkan diri sebagai kepala daerah, tentu aktor memiliki modal yang cukup besar untuk bersaing dengan lawan politik nya. Modal tersebut tidak terlepas dari baik itu modal sosial, modal politik, modal ekonomi dan modal budaya, yang menurut Kacung Marijan semakin besar akumulasi modal yang dimiliki oleh seorang kandidat maka semakin besar pula dukungan yang diperoleh ${ }^{9}$.

Pemanfaatan modal sosial yang dilakukan oleh Deri Asta dan Zohirin Sayuti, antara lain: pengerahan suara karyawan perusahaan tambang, diperkenalkan kepada kerabat oleh kelompok LPM, Motor Trail Adventure, ikatan keluarga Pariaman dan Tanah Datar, Dukungan dan kampanye terselubung afiliasi anggota muhammadiyah, dukungan suara birokrat, berkegiatan dengan kelompok tani dan karang taruna. Pemanfaatan modal politik yang dilakukan oleh Deri Asta dan Zohirin Sayuti antara lain: Partai membentuk tim sukses

\footnotetext{
${ }^{9}$ Op Cit, Kacung Maridjan, hlm 89
} 
,tim sukses melakukan kampanye, blusukan Deri Asta dan Zohirin Sayuti, pembentukan tim pendukung perempuan oleh istri Amran Nur. Pemanfaatan modal ekonomi yang dilakukan oleh Deri Asta dan Zohirin Sayuti antara lain: bantuan dana yang diberikan oleh pengusaha tambang, Penyediaan logistik saat blusukan, memberikan gaji kepada relawan, pembagian kupon bensin, pembelian alat peraga kampanye, bantuan dana yang diberikan oleh pengusaha tambang yang mana hal tersebut dilakukan untuk memperluas pasar pemilih calon tersebut.

\section{DAFTAR PUSTAKA}

Budiardjo, Miriam. (1998). Partisipasi dan Partai Politik. Jakarta: Yayasan Obor Indonesia

Budiardjo, Miriam. (2008). Dasar-Dasar Ilmu Politik. Jakarta: Gramedia Pustaka Utama

Budiyono, Kabul. (2012). Teori dan Filsafat Politik. Bandung: Alfabeta

Bungin, Burhan. (2006). Metode Penelitian Kualitatif. Jakarta: Rajawali Pers

Danim Kuntjojo, Sudarwan. (2009). Metode Penelitian. Kediri

Firmanzah. (2010). Persaingan Legitimasi Kekuasaan, dan Marketing Politik. Jakarta:Yayasan obor indonesia.

Fukuyama, Francis. (2002). Kebajikan Sosial dan Penciptaan Kemakmuran. Yogyakarta: Qalam

Hermawanti, (Mefi. 2002). "Penguatan dan Pengembangan Modal Sosial Masyarakat Adat”, Laporan Need Assesment Pemberdayaan Masyarakat Adat di Nusa Tenggara timur. IRE Yogyakarta.

Lexy J. Moleong. (2004). Metode Penelitian Kualitatif. Bandung: PT.Remaja Rosdakarya

Philpott, Simon. (2003). Meruntuhkan Indonesia, Politik Postkolonial dan Otoritarianisme. Yogyakarta: LkiS

Satori, Djam’an. (2009). Metode penelitian Kualitatif. Bandung: Alfabeta

Sugiyono. (2012). Metode Penelitian Kualitatif dan R\&D. Bandung: Alfabeta

Anshar. (2016). Politik Jejaring Saudagar Bugis. Tesis UGM

GB Suprayoga. (2008). identitas Kota Sawahlunto Paska Kejayaan pertambangan batu bara. Jurnal ITB

Haryanto. (2005).Kekuasaan Elit (suatu bahasan pengantar). JIP UGM 
Imawan, Ridho. (2014). Pemilihan Langsung Kepala Daerah di Indonesia: Beberapa Catatan Kritis Untuk Partai Politik. Jurnal penelitian politik. vol $11 \mathrm{im}$

Nurhasim, Moch. Dkk. (2003). Konflik antar Elit Politik Lokal dalam Pemilihan Kepala Daerah. Jakarta: Pusat Penelitian Politik (P2P) LIPI

Maria, Stella. (2012). Modalitas Dalam Kontestasi Politik (Studi tentang Modalitas dalam Kemenangan Pasangan Hanny Sondakh dan Maximilaan Lomban Pada Pemilukada di Kota Bitung Sulawesi Utara tahun 2010. Tesis UNDIP

Putra, Yovaldri Riki. (2012). Optimalisasi Modal Politik Pasangan Ismet Amzis-Harma Zaldi pada Pemilihan Walikota dan Wakil Walikota Kota Bukittinggi Tahun 2010. Skripsi pada jurusan Ilmu Politik FISIP UNAND

Putri, Masyidan. (2015). Faktor Kemenangan Koalisi Suharsono-Halim dalam Pemenangan Pemilu Kepala Daerah Kabupaten Bantun Tahun 2015.Universitas Muhammadya Yogyakarta.

Rismiati, Arlinda. (2017). Strategi Calon Bupati dalam Memobilisasi Dukungan Supporter Sepak Bola (Studi Kasus: Proses Mobilisasi Pasangan Calon Bupati Hj. Sri Sumarno terhadap Dukungan Supporter Persebumi Saat Pilkada 2010). Thesis UGM

Syahyuti, Ni Nyoman. Peran Modal Sosial (social Capital) Dalam Perdagangan Hasil Pertanian (The Role of Social Caital in Agricultural Trade). Jurnal.2018. Dipublikasikan. Pusat Analisis Sosial Ekonomi. Hlm 69

Zaafriel, Arief. (2016). "Peran Partai Politik Dalam Pemilihan Kepala Daerah:Studi Upaya Partai Golkar dalam Memenangkan Pasangan Calon JuliyatmonoRohadi di Pemilihan Kepala Daerah Kabupaten Karanganyar Tahun 2013. Jurnal Politik Muda. 5(3).

Akhmad Farhan.Memahami Kemenangan Petahana Dalam Pilkada Dari Sudut Pandang Political Branding. http://akhamadfarhan.com/memahami-kemenangan-petahanadalam-pilkada-dari-sudut-pandang-political-branding/

Edi, Suharto. Phd. hhtp://MODAL_SOSIAL_DAN_KEBIJAKAN_SOSIAL

Harian Haluan. (2018). Dua Petahan Tumbang Di Sumbar, www.harianshaluan.com

Haluan, (2016). Tumbangkan Petahana, Deri Asta: Ini Kemeangan Masyarakat Sawahlunto, www.haluan.com. Diakses pada 3 Maret 2017 pukul 10.07 Wib

Indeksnews.com. sosok syafwa Efedi dimata Deri Asta. 2018, www.indeksnews.com

Jamaluddin Ancok. "Modal Sosial, dan Kualitas Masyarakat" Pidato Pengukuhan Guru Besar UGM Yogyakarta 
Kumparan.com. Terbongkar! Ternyata ini yang mendongkrak popularitas DERASZ...www.Kumparan.com

Lihat bps.go.id (online). Jumlah penduduk menurut umum. https//Sawahluntokota.bps.go.id. diakses pada 3 Agustus 2019

Pemanfaatan modal sosial dalam pemenangan calon anggota legislatif pasca pindah dapil pada pemilu legislatif kota surabaya tahun 2014

Petahana Tumbang di Pilkada Sawahlunto, Deri Asta Zohirin Berjaya di Kota Arang. https://sumbar.pekanbaru.tribunews.com/.Diakses pada tanggal 2 Maret 2019 Pukul 20.40 WIB

Pilkada Padang Panjang 2018. https://sumbar.antaranews.com/

Sejarah Kota Sawahlunto, https://portal.sawahluntokota.go.id/sejarah-kota-sawahlunto/, diakses tanggal 5 Agustus 2019.

Sudirman Nasir. SBY antara modal politik dan modal simbolik, dalam http://pemilu.liputan6. com/kolom 